MaPan : Jurnal Matematika dan Pembelajaran

p-ISSN: 2354-6883 ; e-ISSN: 2581-172X

Volume 9, No 2, Dec 2021 (364-378)

DOI: https://doi.org/10.24252/mapan.2021v9n2a12

\title{
ANALYZING CONTENT KNOWLEDGE OF PROSPECTIVE ELEMENTARY SCHOOL TEACHERS ON THE MATERIAL OF FRACTIONAL ARITHMETIC OPERATIONS
}

\author{
Wirda Safriani ${ }^{1)}$, Said Munzir ${ }^{2)}$, M. Duskri ${ }^{3)}$ \\ ${ }^{1}$ Master Program of Mathematics Education, Syiah Kuala University \\ 2Study Program of MIPA Matematics, Syaih Kuala University \\ 3Study Program of Mathematics Education, Islam Ar-Raniry University of Banda Aceh \\ 1,2,3Jl. Tgk. Hasan Krueng Kalee, Banda Aceh, Indonesia \\ Email: wirda.safriani09@gmail.com¹), smunzir2001@yahoo.com²), \\ m.duskri@ar-raniry.ac.id ${ }^{3}$
}

Received September 29, 2021; Revised December 24, 2021; Accepted December 25, 2021

\begin{abstract}
:
Teacher quality is one of the most influential factors in student learning. In-depth material knowledge (content) is very important for prospective teachers who will one day become teachers. Thus, analyzing and describing the Content Knowledge (CK) of prospective teachers needs to be done. The purpose of this study is to describe the CK of prospective elementary school teachers $(\mathrm{SD} / \mathrm{MI})$ on the material of fractional arithmetic operations. The subjects of this study were three students from Ar-Raniry State Islamic University of Banda Aceh. This research includes qualitative descriptive research, so that the data were analyzed using qualitative data analysis, namely data reduction, data presentation, and drawing conclusions. Data collection in this study was carried out through tests and combined with interviews so that the instruments used were test questions and interview guidelines. The study results indicate that the content knowledge of the three elementary teacher candidates was still weak, there were teacher candidates who did not understand the arithmetic operation hierarchy and still made carelessness in the concept of fractional arithmetic operations.
\end{abstract}

Keywords: Content Knowledge, Counting Operations, Fractions

\section{ANALISIS CONTENT KNOWLEDGE CALON GURU SD/MI PADA MATERI OPERASI HITUNG PECAHAN}

\begin{abstract}
Abstrak:
Kualitas guru merupakan salah satu faktor yang paling berpengaruh dalam pembelajaran siswa. Pengetahuan materi (konten) yang mendalam sangat penting dimiliki oleh calon guru yang suatu saat akan menjadi guru. Dengan demikian menganalisis dan mendeskripsikan Content Knowledge (CK) calon guru perlu dilakukan. Tujuan penelitian ini untuk mendeskripsikan CK calon guru Sekolah Dasar (SD/MI) pada materi operasi hitung pecahan. Subjek penelitian ini berjumlah tiga orang mahasiswa dari Universitas Islam Negeri Ar-Raniry Banda Aceh. Penelitian ini termasuk penelitian deskriptif kualitatif, sehingga data dianalisis menggunakan analisis data kualitatif, yaitu reduksi data, penyajian data, dan
\end{abstract}


penarikan kesimpulan. Pengumpulan data pada penelitian ini dilakukan melalui tes dan dipadu wawancara, sehingga instrumen yang digunakan ialah soal tes dan pedoman wawancara. Hasil penelitian menunjukkan bahwa pengetahuan konten (content knowledge) ketiga calon guru SD/MI dapat dikatakan masih lemah, terdapat calon guru yang tidak memahami hierarki operasi hitung, dan masih melakukan kecerobohan-kecerobohan pada konsep operasi hitung pecahan.

Kata Kunci: Content Knowledge, Operasi Hitung, Pecahan

How to Cite: Safriani, W., Munzir, S., \& Duskri, M. (2021). Analyzing Content Knowledge of Prospective Elementary School Teachers on The Material of Fractional Arithmetic Operations. MaPan: Jurnal Matematika dan Pembelajaran, 9(2),

364-378.

https:/ / doi.org/10.24252/mapan.2021v9n2a12.

\section{INTRODUCTION}

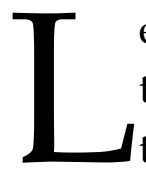

earning achievement of students in a lesson is highly expected for a teacher. Not only can students' learning achievement be measured by

their success in competitions both within and outside the school setting, but also by the outcomes of their classroom learning. This shows that the quality of teachers in determining the most appropriate learning process for the students affects student progress. According to the Deputy for Education and Religion Coordination of the Coordinating Ministry for Human Development and Culture (Kemenko PMK), Agus Sartono (2020) said that one of the key aspects of student learning success is the teacher, where teachers play an important role in education in addition to infrastructure, curriculum, and other supporting aspects. Ilyas Ismail (2010) stated that the achievement that indicates low mathematical competence is influenced by the teacher's quality. Additionally, the research results indicate a positive relationship between knowledge possessed and the quality of learning (Lee \& Santagata, 2020). Therefore, comprehensive knowledge for a teacher or teacher candidate is a very important factor to have.

Understanding comprehensive mathematics material (content) is essential for prospective teachers, as the quality of future teaching is defined and is ultimately their duty. Based on the researcher's preliminary research, which was supported by the findings of other studies, the majority of students encountered conceptual errors for fractional arithmetic operations (Safriani, Maulidi, Munzir, \& Duskri, 2019). Safriani, Maulidi, Munzir, and Duskri 
(2019). According to the Program for International Student Assessment (PISA) in 2018, the average mathematical competence of Indonesian students was 386, placing them in the bottom six countries (OECD, 2018). Additionally, according to Trends in International Mathematics and Science (TIMSS) study in 2015, Indonesian students' performance level was 46 out of 51 nations, with 397 of an average score.

According to TIMSS, in 2019, less than half of students have teachers who are professional in learning and can influence students' critical thinking skills, while $70 \%$ of other students have teachers who need further develop their professionalism. Based on preliminary research and reports from PISA and TIMSS, the content knowledge of teachers/prospective teachers plays an important role in overcoming low student learning outcomes and students' difficulties in learning fractional arithmetic operations. Content knowledge of teachers/prospective teachers is also part of the professionalism of teachers/prospective teachers. Therefore, research on the content of a teacher is important since he is still a prospective teacher. The professional development of teachers has been regulated in Government Regulation Number 74 of 2008 concerning teachers and lecturers as a juridical basis on competence and certification. The first article states that a professional teacher must meet several requirements, including academic qualifications, competencies, educator certification, physical and spiritual fitness, and the ability to realize national education goals. Additionally, the second article explains that the competencies in the first article are a set of knowledge, skills, and behaviors that teachers must possess, live, master, and actualize in carrying out professional duties. The teacher competencies in section one of article one in Government Regulation number 74 are pedagogic, personal, social, and professional competencies. The second section of the first article defines professional competence as teachers' ability to master the fields of science, technology, and/or arts and culture in which they are certified. Teachers at least must master the subject matter broadly and deeply under the standard content of the educational unit program, the subjects and groups of subjects to be taught, as well as the concepts and methods of relevant scientific, technological, or artistic disciplines that conceptually overlap or are coherent with the educational unit program, subject and/or group of subjects to be taught. In other words, professional competence is known as content knowledge. Sanjaya (2010) states that a good teacher is a teacher who can master the subject matter well and use it effectively as a learning resource for 
students. In addition, Rahmawati (2014) states that teachers' weak mastery of content is an obstacle for them to understand and overcome students' learning difficulties or misconceptions. As a result, professional teachers need to have Content Knowledge (CK).

A professional teacher has good Pedagogical Content Knowledge (PCK). Shulman (1986) defines PCK as a unique knowledge that combines pedagogic knowledge and content knowledge to teach the material to students easily. One aspect of PCK related to content knowledge is an in-depth understanding of basic mathematics and procedural knowledge.

Research on content knowledge (CK) for prospective teachers is interesting to be explored. One of the researchers, (Lisnani, 2019), who examined the initial conceptual understanding of elementary school teacher candidates of fractions, found that elementary school teacher candidates' conceptual understanding of fractions was still low at 33.82\%. Furthermore, the research of Santi, Maharani, and Setiyani (2020) indicated that students made errors in solving story form problems on fractions. The errors were unable to notate fractional numbers when given a picture, unable to know the meaning of fractions, unable to add mixed fractions with different denominators, unable to perform mixed fraction subtraction operations, unable to perform division of natural numbers by fractions, and unable to convert mixed fractions into ordinary fractions.

The studies mentioned previously discuss the basic concepts of elementary school teacher candidates. This study further discusses the indepth understanding of basic mathematics and procedural knowledge, which are aspects of Pedagogical Content Knowledge (PCK). This further discussion needs to be carried out because it is the most important aspect in the PCK of prospective teachers to meet the professional requirements as teachers, especially Content Knowledge. The difference between this research and existing research is that this research discusses more deeply related to procedural knowledge and in-depth understanding of elementary mathematics teacher candidates for elementary teachers on fractional arithmetic operations while existing research only discusses mistakes made by prospective teachers. Therefore, researchers are interested in discussing the most important aspects for prospective teachers.

Based on the researchers' explanations, the purpose of this study is to describe procedural knowledge and in-depth understanding of basic mathematics for elementary teachers on fractional arithmetic operations. 


\section{METHODS}

This study aims to describe the Content Knowledge of prospective elementary school teachers on fractional arithmetic operations. The research subjects were three teacher candidates from elementary school teacher education at the Ar-Raniry State Islamic University in Banda Aceh. The three teacher candidates are PT-1, PT-2, and PT-3. The research subject was taken using the purposive sampling technique with specific considerations. These considerations are based on a GPA > 3.00, having met all the requirements for graduation, and is ready to serve in school. The research subjects only consisted of three prospective teachers because the data was saturated and did not provide new information. This research was conducted from 17 July 2020 to 10 October 2020.

Content Knowledge aspects examined in this study are procedural knowledge and an in-depth understanding of basic mathematics. The indicators discussed in procedural knowledge and in-depth understanding of basic mathematics are that prospective teachers can understand the hierarchy of arithmetic operations and problem-solving procedures and understand the concepts of fractional arithmetic operations.

Data collection in this study was carried out using tests and interviews. The test instrument used in this study is adapted from $\mathrm{An}, \mathrm{Kulm}$, and $\mathrm{Wu}$ (2004); Isiksal and Cakiroglu (2011) and validated by three expert lecturers. For the Content Knowledge data of prospective teachers to be valid, this study uses time triangulation. Furthermore, the data were analyzed by Milles and Huberman analysis techniques, namely data collection, data reduction, and conclusions. After the data is obtained, the researcher performs data reduction, namely sorting out important data that can be used in research and discarding data that is not needed. Then, the next step is to present the important data in the aspects studied. Then draw conclusions based on tests and combined interviews. Initially, conclusions were drawn based on each test and combined with interviews, and finally, major conclusions were drawn from each conclusion obtained. The consistency of Content Knowledge data combined with interviews during the first and second tests resulted in the conclusion.

\section{RESULTS AND DISCUSSION}

After conducting the research on three prospective elementary school teachers, the data obtained were analyzed. The research findings obtained by researchers are described as follows. 
In terms of procedural knowledge and in-depth understanding of basic mathematics, data were obtained from test number 1 combined with interviews twice. Table 1 below summarizes the test results from the 1st Prospective Teacher (PT-1) at the first test combined with an interview.

Table 1. PT-1's Answer to the First Test Combined with Interview

\begin{tabular}{|c|c|}
\hline PT-1's answer to the first test & Revision during interview \\
\hline $\begin{aligned} & 2 \frac{3}{5}-1+2 \frac{2}{5}: \frac{1}{4} \times 1 \frac{2}{9} \\
= & \frac{13}{5}-1+\frac{12}{5}: \frac{1}{4} \times \frac{11}{4} \\
= & \left(\frac{13}{5}-\frac{1}{1}+\frac{12}{5}\right):\left(\frac{1}{4} \times \frac{17}{9}\right) \\
= & (2,6-1+2,4):\left(\frac{11}{36}\right) \\
= & 6: 0,305 \\
= & 19,67\end{aligned}$ & $\begin{aligned} & 2 \frac{3}{5}-1+2 \frac{2}{5}: \frac{1}{4} \times 1 \frac{2}{9} \\
= & \left(\frac{13}{5}-\frac{1}{1}+\frac{12}{5}\right) \cdot\left(\frac{1}{4} \times \frac{11}{9}\right) \\
= & \left(\frac{26}{10}-\frac{10}{10}+\frac{24}{10}\right):\left(\frac{1}{4} \times \frac{11}{9}\right) \\
= & \left(\frac{40}{10}\right):\left(\frac{11}{36}\right) \\
= & =\frac{40}{10}: \frac{11}{36} \\
= & \frac{40}{10} \times \frac{36}{11} \\
= & =\frac{1440}{110}\end{aligned}$ \\
\hline Figure $1 . \mathrm{PT}-1$ 's answer to the first test & Figure 2. PT-1's answer revision \\
\hline
\end{tabular}

Figure 1 illustrates that PT-1 can correctly apply the concepts of converting mixed fractions into ordinary fractions and counting fraction operations. However, the answer also shows that PT-1 does not follow the arithmetic operation hierarchy, and PT-1 solves by converting all fractions into decimal numbers. Researchers suspect that understanding the concept of PT-1 in solving the given problem only uses this method. After interviewing PT-1, the answer is indicated in Figure 2: PT -1 solves the problem without converting fractions to decimal numbers. Still, PT -1 does not solve according to the operating hierarchy described in Figure 1. Next, the researchers conducted the second test with an interview to get the valid data of PT-1 related to the hierarchy of arithmetic operations. PT-1's results of the second test with the interview are shown in table 2. 
Table 2. PT-1's Answer to the Second Test Combined with Interview

PT-1's answer to the second test
$=\left(\frac{2}{1}-\frac{1}{4}\right): \frac{2}{3}+3 \frac{2}{5} \times 1 \frac{3}{4}$
$\left(\frac{8}{4}-\frac{1}{4}\right):\left(\frac{2}{3}+\frac{17}{5}\right) \times 1 \frac{3}{4}$
$=\left(\frac{7}{4}\right):\left(\frac{10}{15}+\frac{51}{15}\right) \times 1 \frac{3}{4}$
$=\frac{7}{4}=\frac{61}{15} \times 1 \frac{3}{4}$
$=\frac{7}{4}=\frac{6}{15} \times \frac{7}{4}$
$=\frac{7}{4}=\left(\frac{61}{15} \times \frac{7}{4}\right)$
$=\frac{7}{4}: \frac{427}{60}$
$=\frac{7}{4} \times \frac{60}{427}$
$=\frac{420}{170}$
Figure 3. PT-1's answer to the second test
$=$

Figure 3 describes that PT- 1 correctly converts mixed fractions into ordinary fractions, accurately performs arithmetic operations, and does not convert fractions into decimal numbers. However, PT-1 is incorrect due to PT1 failing to complete following the operating hierarchy. Meanwhile, PT- 1 did not provide answer revision throughout the interview, but PT-1 explained how to solve the problem. Researchers suspect that PT-1 does not understand the hierarchy of operations. In the interview, information was obtained that PT-1 can understand the concept of fractional arithmetic operations but not the hierarchy of operations.

Based on the results of the first and second tests combined with interviews, it can be concluded that PT-1 understands the concept of fractional arithmetic operations but does not comprehend the hierarchy of arithmetic operations.

The test results of the 2 nd Prospective Teacher (PT-2) at the 1st test combined with interviews are illustrated in table 3 as follow. 
Table 3. PT-2's Answer to the First Test Combined with Interview

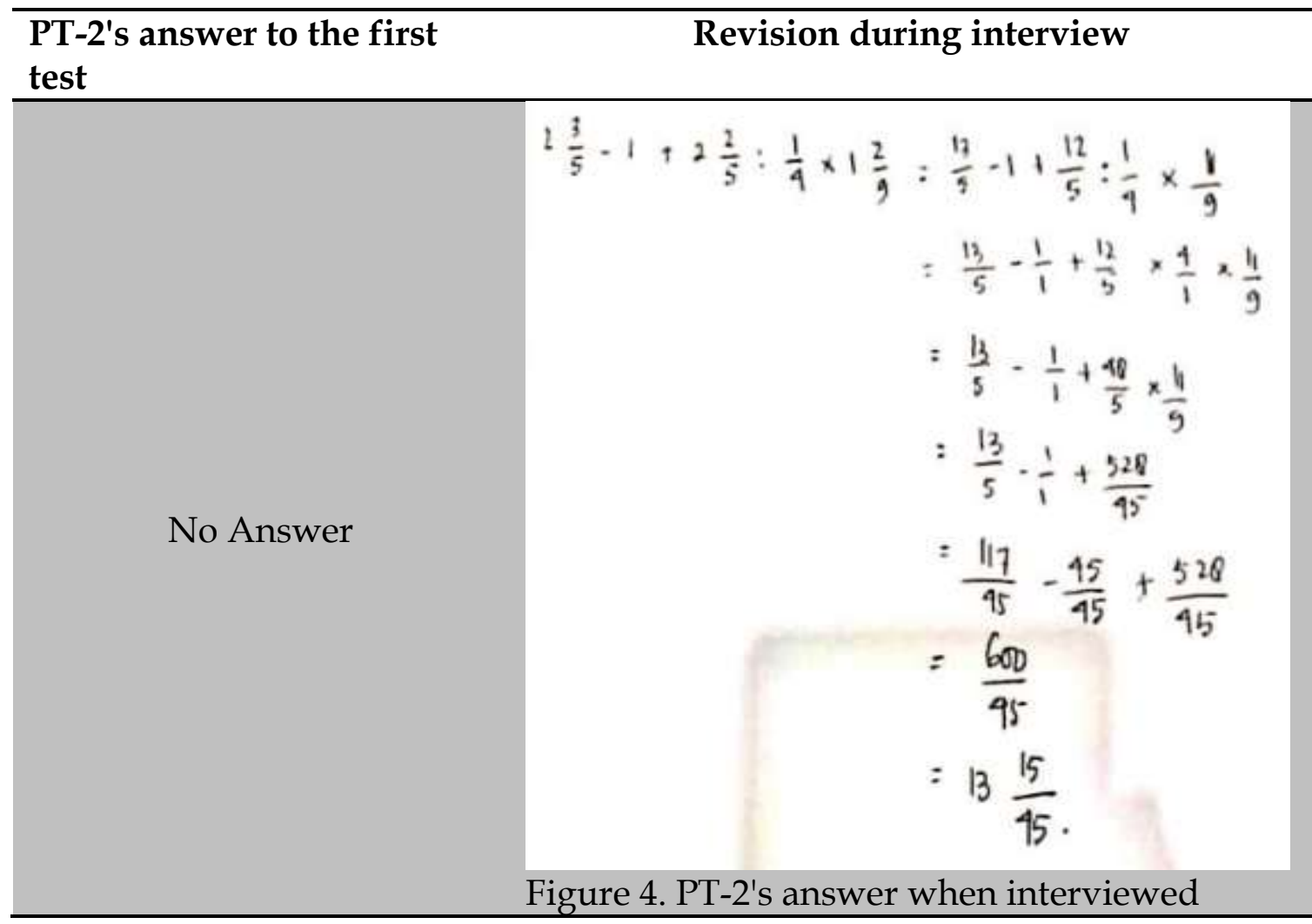

On the first test, PT-2 did not answer the questions. PT-2 stated during the interview that she forgot the concept of fractional arithmetic operations throughout the test. However, she had already remembered the concept of fractional arithmetic operations when interviewed, which enabled her to solve the problem, as illustrated in Figure 4. As shown in Figure 4, PT-2 has solved the problem using the concept of fractional operations and understands the hierarchy of arithmetic operations. Then, the researchers ran a second test and combined interviews to determine the validity of PT-2's data about the concept of fractional arithmetic operations and the hierarchy of arithmetic operations. The test results from PT-2 combined with the interview in the second test are shown in table 4 . 
Table 4. PT-2's Answer to the Second Test Combined with Interview

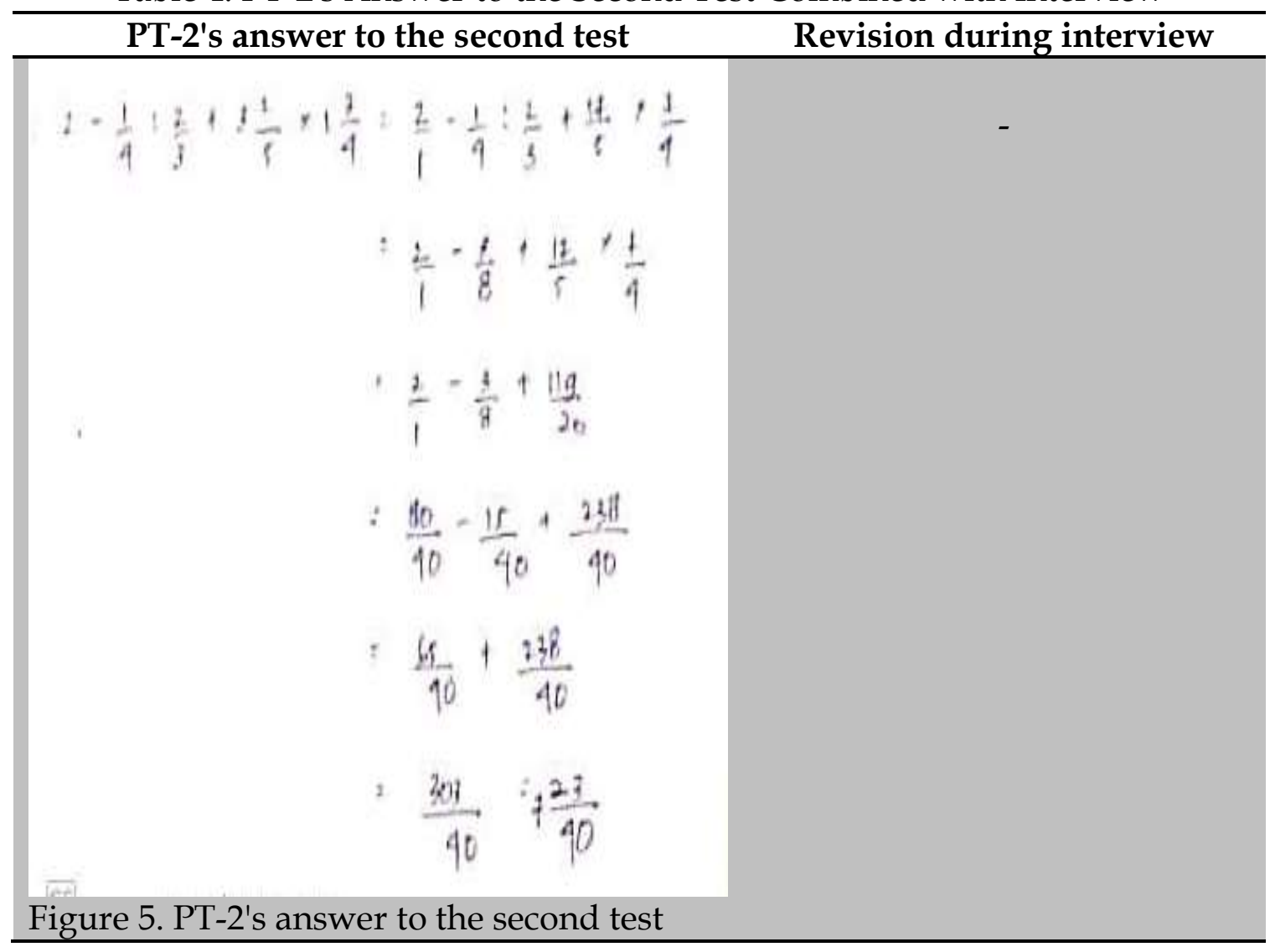

Figure 5 describes that PT-2 applies the concept of converting mixed fractions into ordinary fractions, uses the concepts of addition, subtraction, multiplication, and division of fractions correctly, and understands the hierarchy of arithmetic operations. Likewise, PT-2 adequately explained problem-solving well during the interview using the hierarchy of mathematical operations and the concept of fractional operations. Based on the results of the first and second tests combined with interviews, it can be concluded that PT-2 understands the concept of fractional arithmetic operations and the hierarchy of arithmetic operations.

The test results of the 3rd Prospective Teacher (PT-3) at the first test combined with the interview are illustrated in table 5. 
Table 5. PT-3's Answer to the First Test Combined with Interview

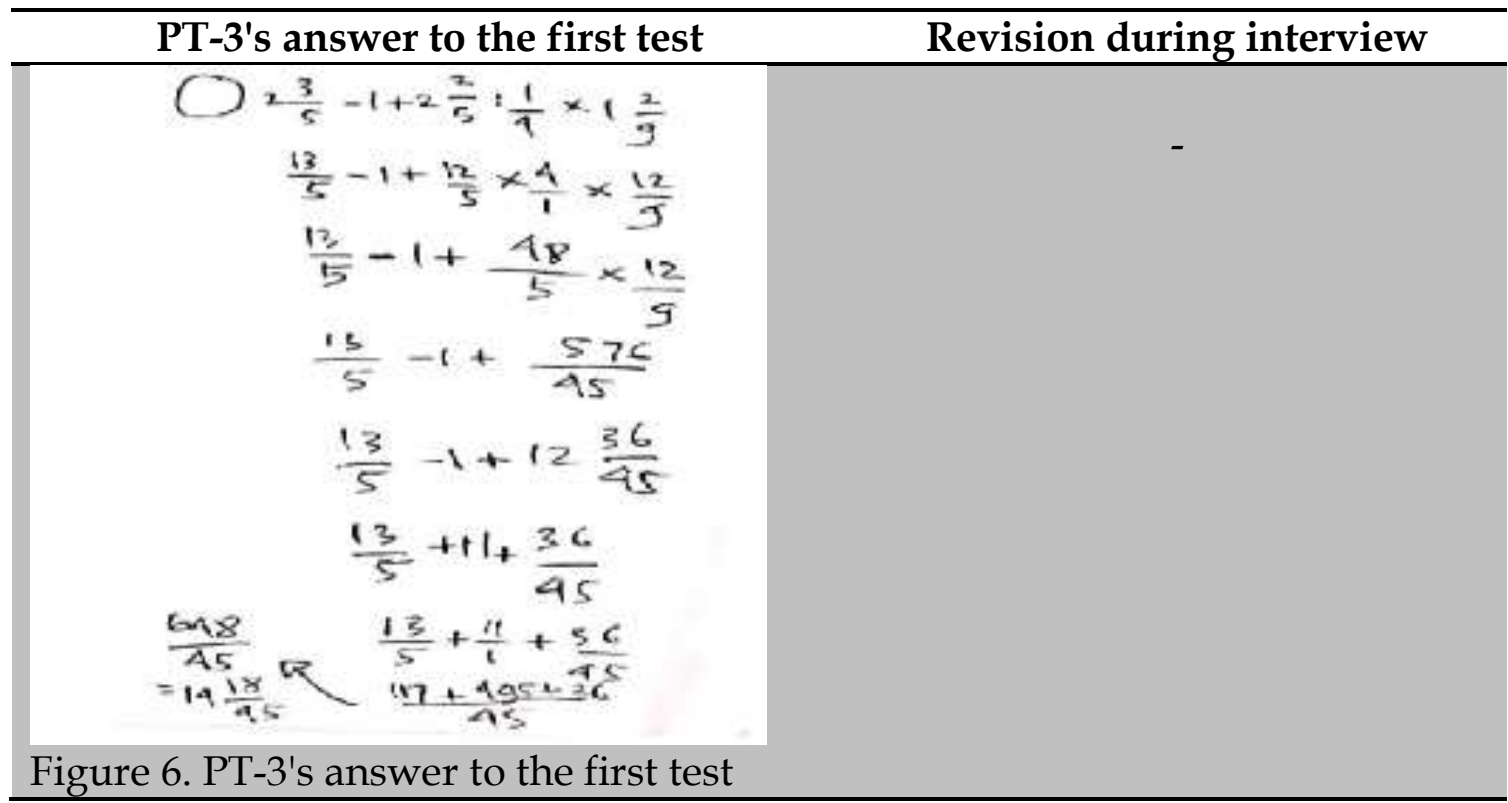

Figure 6 describes that PT-3 can solve problems following the operating hierarchy. However, the final result is false because PT-3 incorrectly converts $1 \frac{2}{9}$ into a common fraction. Researchers suspect the error was only due to carelessness. PT-3 can explain her mistake based on the interview results. The researchers conducted a second test and combined interviews to get the validity of the PT-3 data related to the hierarchy of arithmetic operations. Table 6 summarizes the findings of PT-3 combined with the interview result at the second test.

Table 6. PT-3's Answer to the Second Test Combined with Interview

\begin{aligned} \hline PT-3's answer to the second test & Revision during interview \\ $=2-\frac{1}{4} & =\frac{2}{3}+3 \frac{2}{5} \times\left(\frac{3}{4}\right. \\ = & =\frac{3}{2}+\frac{17}{5} \times \frac{7}{4} \\ & =2-\frac{3}{8}+\frac{119}{20} \\ & =2-\frac{15+238}{40} \\ & =2-6 \frac{13}{40} \\ & =-9 \frac{13}{40}\end{aligned}$


Figure 7 shows that PT-3 applies the concept of converting mixed fractions into ordinary fractions and the concepts of addition, subtraction, multiplication, and division of fractions correctly. PT-3 also understands the hierarchy of arithmetic operations. However, PT-3's answer is incorrect for the solution of $2-\frac{3}{8}+\frac{119}{20}=2-\frac{15+238}{40}=2-\frac{253}{40}$. Researchers suspect the error was only due to carelessness. Similarly, throughout the interview, PT-3 described problem-solving using the hierarchy of mathematical operations and the concept of fractional operations, and he/she expressed confidence in his/her responses.

Errors on the second test conducted by PT-3 can be harmful to students. PT-3 was supposed to be aware of the inaccuracy. A third test was carried out combined with interviews to ensure further the researcher about the mistakes caused by PT-3. The results of the third test are shown in table 7.

Table 7. PT-3's Answer to the Third Test Combined with Interview

\section{PT-3's answer to the third test}

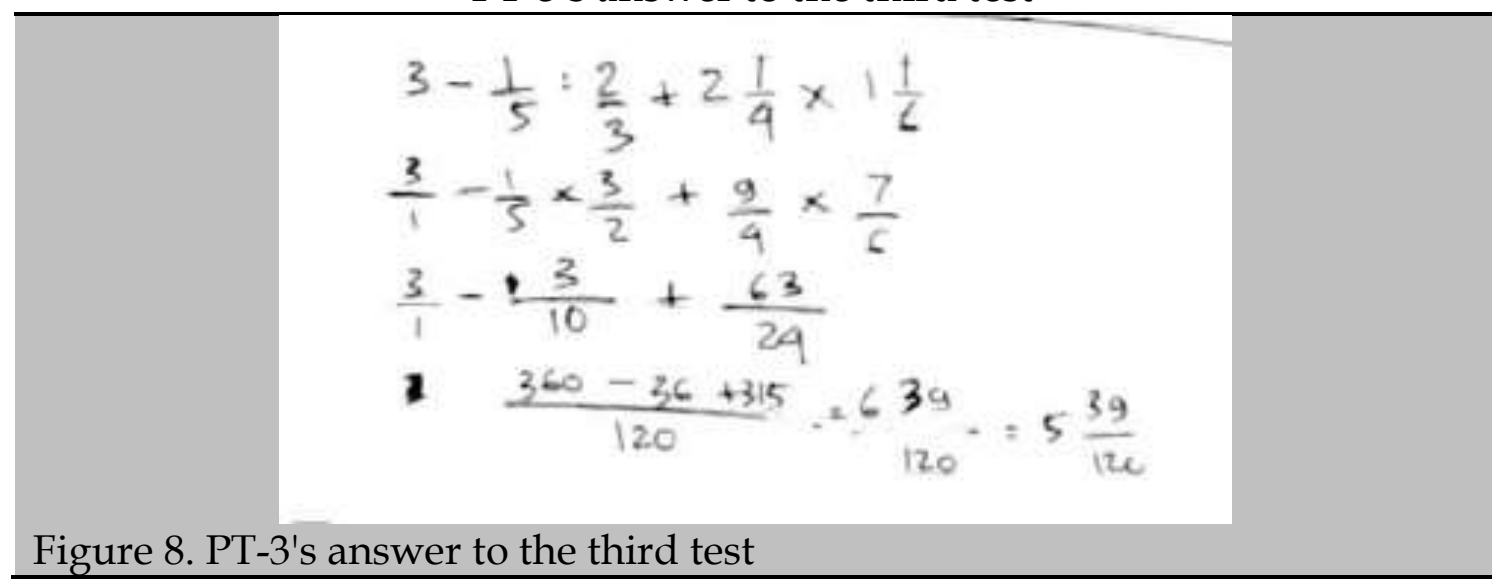

Figure 8 illustrates that PT-3 has successfully applied the concepts of converting mixed fractions into ordinary fractions and counting fraction operations. PT-3 also understands the hierarchy of arithmetic operations. PT-3 was able to explain the completion according to the concept during the interview and did not make any mistakes similar to those in the second test. However, it is possible that these faults can occur at another time.

Based on the results on the first, second, and third tests combined with interviews, it can be concluded that PT-3 understands the concepts of fractional arithmetic operations and the hierarchy of arithmetic operations but is often careless in answering questions. 
A teacher is an educator who has various kinds of responsibilities, including educating students, teaching material concepts to students, and developing themselves into professional teachers. One of the requirements for professional development of teachers based on Government Regulation No. 74 of 2008 is that a teacher must have various competencies, namely paedagogic, personal, social, and professional competencies. Regarding professional competence in the Government Regulation, the teacher must possess comprehensive and in-depth knowledge of the subject matter, also known as content knowledge.

Content knowledge is information about the subject matter that the teacher will teach the students. Content knowledge can consist of concept explanations, analogies from understanding concepts, and organizing between concepts. The quality of teacher/prospective teacher content knowledge significantly impacts the learning process and becoming a professional teacher.

Mathematics is one of the content knowledge that must be taught to students. According to Auslin (2021), in The National Interest, a country can develop its economy widely, and companies can become very advanced due to the underlying mathematics. In addition, the importance of studying mathematics is also because mathematics can shape a person's mindset to be intelligent, creative, and independent (Khuzaeva, 2014).

Based on the discussion of the Content Knowledge (CK) aspects studied in this study, several important findings should be discussed. The findings in this study are the aspects of procedural knowledge and in-depth understanding of basic mathematics related to the concept of counting fractions and knowledge of the arithmetic operation hierarchy from the three prospective teachers. It was discovered that there were prospective teachers who made procedural errors and carelessness.

Procedural errors made by prospective teachers were caused by a lack of understanding of the arithmetic operation hierarchy. For example, PT-1 made a mistake because solving the problem did not follow the hierarchy of arithmetic operations. The consistency of PT-1 did not understand the arithmetic operation hierarchy was also seen during the interview and the second test combined with the interview. The findings indicate that there are prospective teachers who do not understand the hierarchy of arithmetic operations in line with the results of research by Anugrahana (2020); (Nurlita, 2016). Anugrahana (2020) stated that there were two mistakes made by PGSD (Elementary Teacher Education Department) students in completing the 
concept of integer arithmetic operations. These are conceptual and procedural errors, respectively. One of the conceptual errors made by students is a mixed arithmetic operation error of multiplication, addition, and subtraction. Meanwhile, one of the procedural errors made by students is a failure to recognize the hierarchy when addition, subtraction, multiplication, and division are included in the mixed arithmetic operation. This study also shows that some students/prospective teachers make the same mistakes as shown by Anugrahana (2020). Likewise, research by (Nurlita, 2016) mentions the same error, namely, students completing mixed operations without consideration for the order of completion.

This study also discovered carelessness in fraction counting procedures, such as PT-3 in converting mixed fractions to common fractions, namely PT-3 changing $1 \frac{2}{9}$ to $\frac{12}{9}$. This is a thoughtless error because PT-3 is aware of her error and can explain the right change. This carelessness is also found in the research of Nurlita (2016). They found that while most students can complete addition and subtraction of ordinary fractions when the fraction is in the form of mixed fractions, students make errors, indicating that they did not understand the fraction concept correctly.

Based on the findings obtained can be fatal for the world of mathematics education. The benefits of this research are to provide an overview of the content knowledge of prospective SD/MI teachers on fractional arithmetic operations and as input and reflection for prospective teachers and lecturers in basic mathematics courses. Therefore, with this research, it is hoped that the lecturers who support courses should pay more attention to strengthening the concept by assisting prospective teachers. In addition, prospective teachers must continue to improve their knowledge related to the concept of fractional arithmetic operations and the hierarchy of arithmetic operations by improving the learning process outside the classroom because concepts knowledge and the hierarchy of arithmetic operations are basic knowledge must be known. Anugrahana (2020) states that if basic knowledge is wrong, it will be fatal to the formation of other concepts and may also experience errors.

\section{CONCLUSION}

This research shows that the content knowledge of the three teacher candidates is still lacking and weak. Some prospective teachers do not yet 
understand the hierarchy of arithmetic operations, and they are also still making careless concepts of fractional arithmetic operations.

\section{ACKNOWLEDGMENT}

The researchers would like to express their gratitude to all those who have helped them write this article, both the supervisors, the head of the PGMI (Madrasah Ibtidaiyah Teacher Education) Study Program and the prospective elementary school teachers who agreed to participate as research subjects.

\section{REFERENCES}

An, S., Kulm, G., \& Wu, Z. (2004). The pedagogical content knowledge of middle school, mathematics teachers in China and the U.S. Journal of Mathematics Teacher Education, 7(2), 145-172. https://doi.org/10.1023/ B:JMTE.0000021943.35739.1c.

Anugrahana, A. (2020). Hambatan, solusi dan harapan: pembelajaran daring selama masa pandemi covid-19 oleh guru sekolah dasar. Scholaria: Jurnal Pendidikan Dan Kebudayaan, 10(3), 282-289. https://doi.org/ 10.24246/j.js.2020.v10.i3.p282-289.

Auslin, M. (2021). Michael Auslin. National Interest, 171, 13-15.

Isiksal, M., \& Cakiroglu, E. (2011). The nature of prospective mathematics teachers' pedagogical content knowledge: the case of multiplication of fractions. Journal of Mathematics Teacher Education, 14(3), 213-230. https:/ / doi.org/10.1007/s10857-010-9160-x.

Ismail, M. I. (2010). Kinerja dan kompetensi guru dalam pembelajaran. Lentera Pendidikan: Jurnal Ilmu Tarbiyah Dan Keguruan, 13(1), 44-63. https:// doi.org/10.24252/lp.2010v13n1a4.

Khuzaeva, E. S. (2014). Mengembangkan pola pikir cerdas, kreatif dan mandiri melalui telematika. Jurnal Lingkar Widyaiswara, 1(4), 138-148. Retrieved from https://juliwi.com/published/E0104/Paper0104_138-148.pdf.

Lee, J., \& Santagata, R. (2020). A longitudinal study of novice primary school teachers' knowledge and quality of mathematics instruction. ZDM, 52(2), 295-309. https://doi.org/10.1007/s11858-019-01123-y.

Lisnani, L. (2019). Pemahaman konsep awal calon guru sekolah dasar tentang pecahan. Mosharafa: Jurnal Pendidikan Matematika, 8(1), 61-70. 
https://doi.org/10.31980/mosharafa.v8i1.388.

Nurlita. (2016). Miskonsepsi konsep prasyarat aljabar mahasiswa pendidikan guru madrasah ibtidaiyah. Jurnal Didaktik Matematika, 3(2), 85-95. http://www.jurnal.unsyiah.ac.id/DM/article/view/5686.

OECD. (2018). PISA 2018: Insight and interpretations. In OECD Publishing.

Rahmawati, M. C. (2014). Pengaruh pendidikan profesi guru (PPG) terhadap pengetahuan konten pedagogik (pedagogical content knowledge) guru peserta PPG prajabatan dalam pembelajaran IPS. KEGURU: Jurnal Ilmu Pendidikan Dasar, 26-37.

Safriani, W., Maulidi, I., Munzir, S., \& Duskri, M. (2019). Analysis of students' errors on the fraction calculation operations problem. L-Jabar: Jurnal Pendidikan Matematika, 10(2), 307-318. https://doi.org/10.24042/ajpm. v10i2.5224.

Sanjaya, W. (2010). Strategi pembelajaran berorientasi standar proses pendidikan. Jakarta: Kencana.

Santi, D. P. D., Maharani, A., \& Setiyani. (2020). Analisa kesalahan konsep materi pecahan pada mahasiswa calon guru SD Universitas Swadaya Gunung Jati Cirebon. ELSE (Elementary School Education Journal): Jurnal Pendidikan Dan Pembelajaran, 4(1). https://doi.org/dx.doi.org/ 10.30651/else.v4i1.4381.

Sartono, A. (2020). Guru penentu keberhasilan pendidikan. Kemenko PMK. Retrieved from https://www.kemenkopmk.go.id/guru-penentukeberhasilan-pendidikan.

Shulman, L. S. (1986). Those who understanding: knowledge growth in teaching. Journal Educational Researcher, 15(2), 4-14. https://doi.org/ 10.3102\%2F0013189X015002004. 